UDC 005.591: 334.716: 330.341 .1

JEL Classification: D81, M11, M49, P42

http://doi.org/10.21272/mmi.2018.4-08

Mykolay Vashchenko,

D.Sc., Research Director, WBM Polska Ltd, Poland

Leonid Taraniuk,

D.Sc., Professor, Sumy National Agrarian University, Ukraine

Yuriy Danko,

D.SC., Associate Professor, Sumy National Agrarian University, Ukraine

Karina Taraniuk,

Ph.D., Sumy State University, Ukraine

\title{
ASSESSMENT OF THE TECHNOLOGICAL READINESS OF THE COUNTRIES OF THE WORLD FOR THE RADICAL INNOVATIONS
}

Abstract. The main challenge in increasing the economic efficiency of industrial enterprises is the low level of adaptation to the rapid changes in the market environment and the lack of effective mechanisms to overcome the crisis. Therefore, there is a need for radical methods of innovation management in the companies that are reengineering the business processes. The main purpose of this study is to develop methodological foundations of the mechanism of radical transformation of the business processes at industrial enterprises, which are the elements in shaping the foundation of this mechanism, comprising the theoretical and methodological, organizational, informational, and instrumental basis for his support. This article uses the following methodological approaches: a comparative analysis in the study of the industry over time; empirical method in developing the basic principles of the implementation mechanism of radical transformation; method of system analysis in the formation of elements of organizational and economic support of radical transformation;methods of mathematical statistics - when calculating the index of technological readiness, innovation and integrated index; the method of synthesis to generate main recommendations for the practical implementation of the mechanism of radical transformation. A comparative analysis of the global competitiveness of countries. The evaluation of the competitiveness of Switzerland, Ukraine, South Africa and their ability to carry out the radical innovations, namely the transformations of the business processes based on indicators of technological readiness index, innovation index and integral index of enterprise readiness for the radical transformations, was conducted. The basic prerequisite for the introduction of the radical transformation of business processes industry. Methodological aspects of the mechanism of radical transformation of business process entities containing a backbone of its elements: the block of theoretical, methodological, organizational, informational, instrumental support. Formed recommendations for the effective implementation of this mechanism. Conclusion and prospects of the follow-up research. The Global Competitiveness Index of the World development block of several states for the technological readiness and innovation unit is studied. The assessment of the competitiveness of South Africa and its capacity for radical transformation of business processes is carried out. The basic premise for the radical transformation of business processes, such as re-engineering business processes at the world level is chosen. The theoretical position of the radical transformation of industrial enterprises. Methodological aspects of the mechanism of the radical transformation of the business processes at the economic entities. Practical recommendations for the implementation of this mechanism is formed. The prospects of the follow-up research on this topic should include the implementation mechanism at the application level of the radical transformation of the business processes at the industrial companies considering the specificity of the economies of the surveyed countries.

Keywords: radical transformation, mechanism, business processes re-engineering, industrial enterprise.

Introduction. In the transitional economy, many industrial enterprises face the challenges in their economic activity. The challenges include: reduced profitability of enterprises in the industry, loss of markets for finished products due to the economic and political factors, reducing the rate of return of current capital and reducing its value, increase of the credit debts, lack of standardization of industrial

Cite as: Vashchenko, M., Taraniuk, L., Danko Y., \& Taraniuk, K. (2018). Assessment of the Technological Readiness of the Countries of the World for the Radical Innovations. Marketing and Management of Innovations, 4, 86-97. http://doi.org/10.21272/mmi.2018.4-08 
products and technological processes of the international quality system for the customer countries, a high level of outflow of highly skilled personnel. All the above-mentioned lead to a significant drop in the efficiency of economic activity of business entities under the conditions of crisis economic phenomena. The ineffective governmental industrial policy of many countries should also be noted as it is aimed at decimating the national commodity producer. Accordingly, there is a need for the anti-crisis management in the functioning of industrial enterprises through the development of an effective mechanism for radical transformations of business processes of the economic entities, which refers to the types of innovation activities(new organizational structures aimed at a radical increase in their economic efficiency; managerial methods to which they belong; benchmarking; crowdfunding; fundraising; outsourcing; business process re-engineering; organizational and economic support for the radical changes; economic toolkit containing the business process orientation of the economic monitoring of the $\mathrm{V}$ and $\mathrm{VI}$ technological modes in the enterprises' activity). This mechanism is also based on a comprehensive assessment of the effectiveness of the introduction of radical transformations and will be aimed at significant improvement of the competitiveness of the enterprise in the market. Therefore, the relevance of the subject of this research is indisputable and prompts its scientific substantiation.

Analysis of recent research and publications. Many scholars are involved in scientific research dealing with the transformation of business processes in the enterprises' activity. Thus, the role of institutional transformations in the activities of financial organizations is considered in the work of such scientists as B. D'Espallier, Ya. Goedecke, M. Hudon, R. Mersland (2017).

Scientists M. Jetter, G. Setzer, A. Neus (2009) conducted the assessment of technological innovations and their impact on the business processes of the IT services enterprises during their transformation.

Study of the practical aspects of the business processes re-engineering of industrial enterprises is also important. Particularly, it is the study of flexible manufacturing technologies during the conduct, made by economists F. Chan, B. Jang (2001).

When assessing the radical transformations of business processes, the main factor is the maintenance of a high level of economic security of companies during the redevelopment of business. The study of the level of vulnerability of the security system during the re-engineering of the business processes in the activities of manufacturing companies was highlighted in the work of S. Goal, V. Chen (2008).

Formation of the information system is a necessary lever in creating a controlled subsystem of the organizational and economic support for the radical transformations. Analysis of the implementation of IT support in the activities of firms in India during the implementation of the information provision redesign of the business processes is provided in the work of the scientists B. Bhushan, S. Pandey (2015).

In the economic toolkit of the radical transformations of the enterprises' business processes, an important element is the subsystem of the social and economic provision. M. Lounonen, P. Kess (2002) carried out the study of the team role during the re-engineering of business processes.

An important step is to analyze the branch peculiarities of the company's work in conducting the innovation management of the business processes. S. Al-Somali, R. Gholami, B. Clegg (2009) developed an economic technology acceptance model (TAM) during the redevelopment of business processes in the financial sector of Saudi Arabia.

During the assessment of the radical transformations of business processes, attention should be paid to the partaking of the state institutions. The scholar E. Abu-Shanab (Abu-Shanab, 2015) considered the practical aspects of state regulation of the manufacturing companies re-engineering.

In assessing the radical business processes transformations, it is necessary to consider the risk management subsystem to form a system for preventing the emergence of economic risk of reengineering. The scientists of the Sumy Scientific School chaired by L. G. Melnyk proposed methodological aspects of assessment of the enterprise risk management system during the reengineering of business processes. When implementing the organizational and economic system of 
radical transformations of business processes, it is necessary to consider the peculiarities of the implementation stages. Economists such as L. G. Melnyk, O. V. Kubatko, O. Vik. Kubatko (2016) studied this feature considering the merger of business processes of economic entities at the sector level.

The mechanisms of business processes transformation at the manufacturing companies in the energy sector and the methods for their assessment were proposed by I. M. Sotnik (2016), who also explored the challenges of energy enterprises' functioning and the ways of their solution.

One should also consider the works of foreign scholars-economists S. Demer, S. Dukas, O. Nyerstrasa (2003), who studied the issues of object-oriented patterns of the business process reengineering at the enterprises from different countries of the world.

The issues of economic transformation at the world level were considered in the works of the following scholars, such as M. Lavigne (Lavigne, 1998), who studied economic transformations in Vietnam; R. Ebert (Ebert, 1993) assessed the economic transformations in Eastern Europe; H. Scott (Scott, 1993) compiled a report on the implementation of economic transformations in Central Europe; H. Gabris (Gabrisch, 1998) investigated the transformation in Germany; Duarte M. and Restuccia (2007) considered structural transformations in Portugal; N. Hanna (Hanna, 2011) analyzed the international experience of different countries in conducting the e-transformation; A. Levy (Levy, 1998) developed a tool for the social transformation exploring the experience of the US companies; M. Alekseev (Alexeev, 2007) considered the institutional transformation of the Russian economy; E. Unal (Unal, 2018) analyzed the transformation of the Turkish economy.

The study of technological transformations and their impact on the work of companies in the countries is also significant. These aspects are attended in the research of the scientists: N. Deva, A. Nitu (2018), Debresson (1991), A. Lorentz, T. Sirilly, M. Savona, M. Valente (2016), M. O'Connor (O'Connor, 1993). E. Reuben, S. Soutens (2012), E. Carayannis., S. Slipp (2010) were engaged in the study of the strategic changes at business entities all over the world.

Another important aspect in shaping the concept of technological change is the formation of an effective management of innovations in the course of radical transformations. Scientists Oliynyk V., Kozmenko O., Weibe I., Kozmenko S. (Oliinyk, Kozmenko, Wiebe, Kozmenko, 2018), carried out research of processes of innovation management at the level of production in the work of the enterprise.

Scientists Harlamov G. carried out the discussion of the impact of technological changes on the imbalance of EU companies' revenues, Stavytsky A., Zarotiadis G. (2018). Gassot Yu (Gassot, 2016) investigated the management of financial transformations in the implementation of e-business innovations in the work of country companies. Scientists T. I. Shevchenko, Y. I. Danko, O. O. Krasnorutsky studied the transformational changes in the natural management, namely the waste management in the activity of economic agents of the EU countries. (Shevchenko et al., 2018).

Outstanding components of the general issue considered in the article. In modern world scientific literature there is no unified view of the systemic vision of the mechanism implementation of radical business processes transformations at industrial enterprises and their technological readiness for radical innovations. This issue is also unexplored in the context of systemic shifts in the global economy, the use of measures aimed at overcoming the global financial crisis by enterprises from different countries and adapting them to the changing market conditions.

Purpose of the article. To analyze the global competitiveness of the regions and to identify their technological readiness for radical innovations. The main objectives of the research are to assess the competitiveness of the countries all over the world, including Switzerland, Ukraine, South Africa and their ability to carry out the radical innovations, namely the transformation of business processes; to determine the preconditions for business process re-engineering; to form the elements of organizational and economic support of radical transformations of the enterprises' business processes; to develop the recommendations for its effective implementation. 
Major results of the study. The scientific analysis led to the following: in assessing the global competitiveness of the regions and identifying their technological readiness for the radical innovations, some indicators should be taken into account. They are as follows: the system of economic indicators for assessing the necessity and efficiency of the radical transformations, including the indicators of enterprises' technological readiness, the indicators of innovative activity of the companies when assessing the competitiveness of industrial enterprises of the country and their capacity for the radical change; indicative elements of the organizational and economic support (mechanism) of the radical transformations of business processes.

The level of innovation activity of enterprises at the global level is studied as a prerequisite for radical transformations of the companies based on the Global Competitiveness Report of the world in 2016 (Schwab et al., 2016). This choice of countries is stipulated by the following factors: leader countries; countries in the leader area; countries located in the outside area; outsider countries according to the level of their global competitiveness (Table 1).

Table 1 - Comparative analysis of the global competitiveness of the countries all over the world in 2016, units/rank

\begin{tabular}{|c|c|c|c|c|c|c|c|c|}
\hline $\begin{array}{c}\text { Name of the } \\
\text { economic indices }\end{array}$ & $\begin{array}{l}\text { Switzer- } \\
\text { land }\end{array}$ & USA & Japan & $\begin{array}{c}\text { Austr } \\
\text { alia }\end{array}$ & $\begin{array}{l}\text { South } \\
\text { Africa }\end{array}$ & Brazil & Ukraine & Yemen \\
\hline \multicolumn{9}{|c|}{ Technological readiness block } \\
\hline $\begin{array}{l}\text { New technologies } \\
\text { availability }\end{array}$ & $\begin{array}{l}6,4 \\
(5)\end{array}$ & $\begin{array}{l}6,5 \\
(3)\end{array}$ & $\begin{array}{c}6,2 \\
(12)\end{array}$ & $\begin{array}{l}5,7 \\
(26)\end{array}$ & $\begin{array}{l}5,4 \\
(44)\end{array}$ & $\begin{array}{l}4,4 \\
(85)\end{array}$ & $\begin{array}{l}4,3 \\
(93)\end{array}$ & $\begin{array}{c}2,9 \\
(136)\end{array}$ \\
\hline $\begin{array}{l}\text { Acquisition technology } \\
\text { on the enterprise level }\end{array}$ & $\begin{array}{l}6,1 \\
(1)\end{array}$ & $\begin{array}{l}6,0 \\
(4)\end{array}$ & $\begin{array}{l}5,6 \\
(18)\end{array}$ & $\begin{array}{l}5,4 \\
(25)\end{array}$ & $\begin{array}{l}5,4 \\
(22)\end{array}$ & $\begin{array}{l}4,6 \\
(65)\end{array}$ & $\begin{array}{l}4,4 \\
(74)\end{array}$ & $\begin{array}{c}3,3 \\
(136)\end{array}$ \\
\hline $\begin{array}{c}\text { FDI and the } \\
\text { technology transfer }\end{array}$ & $\begin{array}{l}5,4 \\
(9)\end{array}$ & $\begin{array}{l}5,1 \\
(25) \\
\end{array}$ & $\begin{array}{r}4,9 \\
(32) \\
\end{array}$ & $\begin{array}{r}4,8 \\
(39) \\
\end{array}$ & $\begin{array}{l}4,6 \\
(52) \\
\end{array}$ & $\begin{array}{l}4,5 \\
(63) \\
\end{array}$ & $\begin{array}{c}3,7 \\
(115) \\
\end{array}$ & $\begin{array}{c}2,8 \\
(135)\end{array}$ \\
\hline \multicolumn{9}{|c|}{ Innovation block } \\
\hline Innovation potential & $\begin{array}{l}6,1 \\
(1)\end{array}$ & $\begin{array}{l}5,9 \\
(2)\end{array}$ & $\begin{array}{c}5,1 \\
(21)\end{array}$ & $\begin{array}{l}5,1 \\
(22)\end{array}$ & $\begin{array}{l}5,0 \\
(25)\end{array}$ & $\begin{array}{l}3,9 \\
(92)\end{array}$ & $\begin{array}{l}4,4 \\
(49)\end{array}$ & $\begin{array}{c}3,1 \\
(136)\end{array}$ \\
\hline $\begin{array}{c}\text { Enterprises' costs for } \\
\text { R\&D }\end{array}$ & $\begin{array}{l}6,0 \\
(1)\end{array}$ & $\begin{array}{l}5,7 \\
(2)\end{array}$ & $\begin{array}{l}5,6 \\
(4)\end{array}$ & $\begin{array}{l}4,5 \\
(24)\end{array}$ & $\begin{array}{l}4,2 \\
(30)\end{array}$ & $\begin{array}{l}3,2 \\
(74)\end{array}$ & $\begin{array}{l}3,3 \\
(68)\end{array}$ & $\begin{array}{c}2,2 \\
(137)\end{array}$ \\
\hline $\begin{array}{l}\text { Universities and } \\
\text { production extension } \\
\text { in terms of R\&D }\end{array}$ & $\begin{array}{l}5,8 \\
(1)\end{array}$ & $\begin{array}{l}5,6 \\
(4)\end{array}$ & $\begin{array}{l}4,8 \\
(18)\end{array}$ & $\begin{array}{l}4,3 \\
(33)\end{array}$ & $\begin{array}{l}4,4 \\
(27)\end{array}$ & $\begin{array}{l}3,2 \\
(90)\end{array}$ & $\begin{array}{l}3,5 \\
(57)\end{array}$ & $\begin{array}{c}1,9 \\
(138)\end{array}$ \\
\hline $\begin{array}{l}\text { New technologies } \\
\text { implementation }\end{array}$ & $\begin{array}{l}3,8 \\
(28)\end{array}$ & $\begin{array}{c}4,4 \\
(11)\end{array}$ & $\begin{array}{l}4,0 \\
(16)\end{array}$ & $\begin{array}{l}3,3 \\
(63)\end{array}$ & $\begin{array}{l}2,9 \\
(99)\end{array}$ & $\begin{array}{c}2,7 \\
(112)\end{array}$ & $\begin{array}{l}3,1 \\
(82)\end{array}$ & $\begin{array}{c}2,3 \\
(135)\end{array}$ \\
\hline Patent applications & $\begin{array}{c}313,5 \\
(3)\end{array}$ & $\begin{array}{l}174,9 \\
(10)\end{array}$ & $\begin{array}{c}335,4 \\
(1)\end{array}$ & $\begin{array}{l}76,2 \\
(22)\end{array}$ & $\begin{array}{l}6,5 \\
(47)\end{array}$ & $\begin{array}{l}3,5 \\
(51)\end{array}$ & $\begin{array}{l}3,9 \\
(49)\end{array}$ & $\begin{array}{c}0,0 \\
(121)\end{array}$ \\
\hline $\begin{array}{c}\text { Global } \\
\text { competitiveness index }\end{array}$ & $\begin{array}{c}5,81 \\
(1)\end{array}$ & $\begin{array}{l}5,70 \\
(3)\end{array}$ & $\begin{array}{c}5,48 \\
(6)\end{array}$ & $\begin{array}{l}5,19 \\
(21)\end{array}$ & $\begin{array}{l}4,47 \\
(49)\end{array}$ & $\begin{array}{l}4,06 \\
(75)\end{array}$ & $\begin{array}{l}4,00 \\
(79)\end{array}$ & $\begin{array}{l}2,74 \\
(138)\end{array}$ \\
\hline
\end{tabular}

Sources: compiled by the authors based on Schwab, Sala-i-Martin, Samans, Blanke, 2016.

According to the comparative analysis, there is a large discrepancy of the values of the global competitiveness index between the leader country and the outsider countries. Comparing Switzerland and Yemen, for example, such a change in the global competitiveness index is 3.07 units or 138 ranks. This conditioned by the different levels of technology, innovation, business environment, institutions that influence the formation of the progressive development of the countries and readiness for radical change.

The state of the industrial companies of different countries of the world is characterized by varying degrees of development. Therefore, in the "technological readiness" block an indicator characterizes the 
acquisition technology at the enterprise level. In the leader country (Switzerland), this indicator is 6.1 units. (1 rank), and in the outsider country (Yemen) it is 3.3 units (136th rank).

The range of values of this indicator is 2.8 units (136 ranks) and it characterizes various possibilities of countries to implement the acquisition technology in the activities of industrial enterprises, including the capacity of production structures to the transform business processes. The challenges in the implementation of acquisition technology are the lack of current capital, the lack of skilled workers, and the lack of systematic knowledge in the management of companies on the implementation of the radical technological transformations of the business processes.

The "innovation" block, empathizes the issue of the formation of enterprises' costs on research and development (R\&D), which characterizes the introduction of new scientific, research and development decisions in the production of industrial products.

When comparing this indicator between the leader country (Switzerland) 6.0 units ( 1 rank) and outsider country (Yemen) 2.2 units (137 ranks), the change of this indicator is 3.8 units. (137 ranks), which reflects the various financial capacities of the industrial enterprises of the countries to introduce new innovative solutions in the production of industrial products. The challenge of implementing R\&D in the enterprises' activities is a low level of current capital, the use of outdated technological processes in the production, the lack of an integrated approach to studying the requests of customers of the industrial products.

We shall determine the integral indicator of the competitiveness of a particular country, using the method of assessing the countries' potential competitiveness, Switzerland, South Africa, Ukraine (as a case study), selected on the basis of high, medium and low global competitiveness indicators (Table 1) (Switzerland's Global Competitiveness Index 1 rank, South Africa 49 rank, Ukraine 79 rank among 138 countries).

This indicator differs from the global competitiveness index by a more detailed description of the domestic potential of the country and the effectiveness of its innovation development. In addition, we compute the index of the technological readiness, the index of innovations and the integral index, which contains the readiness of the enterprises of the country to carry out the radical transformations, using the method of mathematical statistics.

The calculation of the indices of Switzerland, Ukraine, and South Africa is presented in Table 2. The output data for the assessment in Table 2 were obtained from the "Report on Global Competitiveness of the Countries of the World in 2016" (Schwab et al., 2016).

In Table 2, all indicators in Switzerland have a maximum value, so the normalization of indicators was not carried out according to the procedure of implementing the method of assessing the competitiveness of the country's potential. The weight of the indicators of Switzerland, Ukraine and South Africa was determined by the expert method, involving the representatives of universities and industrial enterprises, based on an analysis of the global competitiveness indices of the countries of the world in 2016.

The authors calculated the integral index of competitiveness of the countries $\left(I_{c}\right)$ by the method of assessing the competitiveness of the country's potential.

$$
I_{c}=\sum_{i=1}^{n}\left(B_{c} \cdot W_{c}\right)
$$

where $B_{c}$ is the current score of the indicator; $W_{c}$ is the weight of the indicator.

The Technology Readiness Index $\left(I_{t}\right)$ provides an opportunity to determine in a comprehensive manner the level of technological readiness of enterprises to innovate, including a radical transformation of business processes of companies. 
Table 2 - Assessment of the Competitiveness of Switzerland, Ukraine, South Africa and their capacity to conduct radical transformations of the business processes, units

\begin{tabular}{|c|c|c|c|c|c|c|c|}
\hline $\begin{array}{l}\text { Name of economic } \\
\text { indices }\end{array}$ & 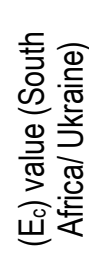 & 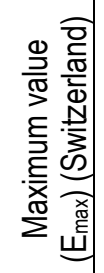 & 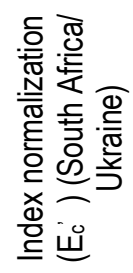 & 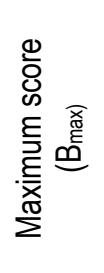 & 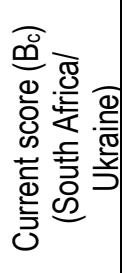 & 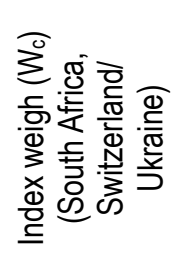 & 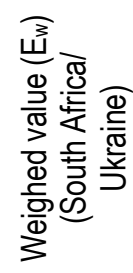 \\
\hline $\begin{array}{c}\text { New technologies } \\
\text { availability }\left(A_{t}\right)\end{array}$ & $\frac{5,4}{4,3}$ & 6,5 & $\frac{0,8}{0,7}$ & 10,0 & $\frac{8,0}{7,0}$ & $\frac{0,1}{0,1}$ & $\frac{0,8}{0,7}$ \\
\hline $\begin{array}{l}\text { Acquisition technology on } \\
\text { the enterprise level }\left(\mathrm{T}_{\mathrm{a}}\right)\end{array}$ & $\frac{5,4}{4,4}$ & 6,1 & $\frac{0,9}{0,7}$ & 10,0 & $\frac{8,0}{7,0}$ & $\frac{0,1}{0,1}$ & $\frac{0,8}{0,7}$ \\
\hline $\begin{array}{c}\text { FDI and the technology } \\
\text { transfer }\left(F_{t}\right)\end{array}$ & $\frac{4,6}{3,7}$ & 5,4 & $\frac{0,9}{0,7}$ & 10,0 & $\frac{9,0}{7,0}$ & $\frac{0,2}{0,1}$ & $\frac{1,8}{0,7}$ \\
\hline Innovation potential $\left(\mathrm{C}_{\mathrm{i}}\right)$ & $\frac{5,0}{4,4}$ & 6,1 & $\frac{0,8}{0,7}$ & 10,0 & $\frac{8,0}{7,0}$ & $\frac{0,2}{0,2}$ & $\frac{1,6}{1,4}$ \\
\hline $\begin{array}{c}\text { Enterprises' cost for } \\
R \& D\left(S_{c}\right)\end{array}$ & $\frac{4,2}{3,3}$ & 6,0 & $\frac{0,7}{0,6}$ & 10,0 & $\frac{7,0}{6,0}$ & $\frac{0,1}{0,1}$ & $\frac{0,7}{0,6}$ \\
\hline $\begin{array}{l}\text { Universities and } \\
\text { production extension in } \\
\text { terms of } R \& D\left(C_{u}\right)\end{array}$ & $\frac{4,4}{3,5}$ & 5,8 & $\frac{0,8}{0,6}$ & 10,0 & $\frac{8,0}{6,0}$ & $\frac{0,1}{0,1}$ & $\frac{0,8}{0,6}$ \\
\hline $\begin{array}{l}\text { New technologies } \\
\text { implementation }\left(I_{n}\right)\end{array}$ & $\frac{2,9}{3,1}$ & 4,4 & $\frac{0,7}{0,7}$ & 10,0 & $\frac{7,0}{7,0}$ & $\frac{0,1}{0,2}$ & $\frac{0,7}{1,4}$ \\
\hline Patent applications $\left(\mathrm{P}_{\mathrm{a}}\right)$ & $\frac{6,5}{3,9}$ & $\begin{array}{c}335 \\
4\end{array}$ & $\frac{0,02}{0,01}$ & 10,0 & $\frac{0,2}{0,1}$ & $\frac{0,1}{0,1}$ & $\frac{0,02}{0,01}$ \\
\hline $\begin{array}{l}\text { Integral competitiveness } \\
\text { index }\left(I_{c}\right)\end{array}$ & \multicolumn{7}{|c|}{$\begin{array}{l}\text { 7,22 (South Africa) / 6,11 (Ukraine)/ } \\
10,00 \text { - leader country (Switzerland) }\end{array}$} \\
\hline $\begin{array}{c}\text { Technological readiness } \\
\text { index }\left(\mathrm{I}_{\mathrm{t}}\right)\end{array}$ & \multicolumn{7}{|c|}{$\begin{array}{l}\text { 1,2 (South Africa) / 0,66 (Ukraine)/ } \\
1,41 \text { - leader country (Switzerland) }\end{array}$} \\
\hline Innovation index (li) & \multicolumn{7}{|c|}{$\begin{array}{l}0,52 \text { (South Africa) } / 0,54 \text { (Ukraine)/ } \\
1,26 \text { - leader country (Switzerland) }\end{array}$} \\
\hline $\begin{array}{l}\text { Integral index of the } \\
\text { enterprises' readiness for } \\
\text { the radical transformation } \\
\text { implementation (Irt) }\end{array}$ & \multicolumn{7}{|c|}{$\begin{array}{l}0,86 \text { (South Africa) /0,76 (Ukraine)/ } \\
1,15 \text { - leader country (Switzerland) }\end{array}$} \\
\hline
\end{tabular}

Sources: calculated by the authors.

The Technology Readiness Index $\left(I_{t}\right)$ contains a block of indicators for technological readiness and is calculated as the geometric value of the indicators: availability of new technologies, enterprise-level acquisition technology, foreign direct investment (FDI) and technology transfer, and consideration of the importance of these indicators.

$$
I_{t}=\sqrt[\sum W_{c\left(I_{t}\right)}]{E_{w\left(A_{t}\right)}^{W_{c\left(A_{t}\right)}} \cdot E_{w\left(T_{a}\right)}^{W_{c\left(T_{a}\right)}} \cdot E_{w\left(F_{t}\right)}^{\left.W_{c(F t}\right)}}
$$


where $E_{w\left(A_{t}\right)}$ is the indicator of the new technologies availability; $W_{c\left(A_{t}\right)}$ is the weight of the indicator of the new technologies availability; $E_{w\left(T_{a}\right)}$ is the indicator of acquisition technology at the enterprise level; $W_{c\left(T_{a}\right)}$ is the weight of the acquisition technology at the enterprise level; $E_{w\left(F_{t}\right)}$ is the Indicator of FDI and technology transfer; $W_{c\left(F_{t}\right)}$ is the importance of FDI and technology transfer; $\sum W_{c\left(I_{t}\right)}$ is the total of the scores' weight.

The Innovation Index $\left(I_{i}\right)$ contains a block of indicators of innovation and is calculated as the geometric value of indicators: the potential for innovation, the cost of enterprises for research and development, the extension of universities and industry in the field of research and development, introduction of new technologies, patent applications and the consideration of the importance of these indicators.

$$
I_{i}=\sqrt[\sum W_{c\left(I_{i}\right)}]{E_{w\left(C_{i}\right)}^{W_{c\left(C_{i}\right)}} \cdot E_{w\left(S_{c}\right)}^{W_{c\left(S_{c}\right)}} \cdot E_{w\left(C_{u}\right)}^{W_{c\left(C_{u}\right)}} \cdot E_{w\left(I_{n}\right)}^{W_{c\left(I_{n}\right)}} \cdot E_{w\left(P_{a}\right)}^{W_{c(P a)}}}
$$

where $E_{w\left(C_{i}\right)}$ is the index of innovation potential; $W_{c\left(C_{i}\right)}$ is the weight of the index of innovation potential; $E_{w\left(S_{c}\right)}$ is the index of enterprises' costs for R \& D; $W_{c\left(s_{c}\right)}$ is the weight of the index of enterprises' cost for R \& $\mathrm{D} ; E_{w\left(C_{u}\right)}$ is an index of the universities and production extension in the field of research and development; $W_{c\left(C_{u}\right)}$ is the weight of the index of the universities and production extension in the field of research and development; $E_{w\left(I_{n}\right)}$ is the index of introduction of new technologies; $W_{c\left(I_{n}\right)}$ is the weight of index of the new technologies introduction; $E_{w\left(P_{a}\right)}$ is the index of patent applications; $W_{c\left(P_{a}\right)}$ is the weight of the index of patent applications; $\sum W_{c\left(I_{i}\right)}$ is the weight of the scores.

The Index of Innovations $\left(I_{i}\right)$ allows systematically determining the level of innovation activity of the industrial enterprises during the establishment of the readiness for radical transformations of business processes at the industrial companies.

The integral index of enterprises readiness for radical transformation $\left(I_{r t}\right)$ contains the index of technological readiness, the index of innovations and is calculated as the geometric value of the index of technological readiness, the index of innovations and the weight of the indicated indices, as the sum of the significance of indices contained in the calculation of the indices data.

$$
I_{r t}=\sqrt{I_{t}^{\sum W_{c\left(I_{t}\right)}} \cdot I_{i}^{\sum W_{c\left(I_{i}\right)}}}
$$

where $I_{t}$ is the index of technological readiness; $W_{c\left(I_{t}\right)}$ is the weight of the technology readiness index; $I_{i}$ is the index of innovations; $W_{c\left(I_{i}\right)}$ is the weight of the innovation index.

This index provides an opportunity to comprehensively determine the level of readiness of the industrial enterprises to carry out the radical transformations of the business processes taking into account the level of technological readiness and the level of innovation development.

The detailed calculation of the integral competitiveness index, the index of technological readiness, the index of innovations, the integral index of enterprise readiness for the radical transformation is presented in Table 3. 
Table 3 - Calculation of the integral competitiveness index, the index of technological readiness, the index of innovations and the integral index of enterprise readiness for the radical transformations

\begin{tabular}{|c|c|c|c|}
\hline Index & $\begin{array}{l}\text { Index calculation } \\
\text { (Switzerland) }\end{array}$ & $\begin{array}{c}\text { Index calculation } \\
\text { (Ukraine) }\end{array}$ & $\begin{array}{l}\text { Index calculation } \\
\text { (South Africa) }\end{array}$ \\
\hline$I_{c}$ & $\begin{array}{l}I_{\mathrm{c}}=10 \cdot 0,1+10 \cdot 0,1+10 \cdot 0,2+ \\
10 \cdot 0,2+10 \cdot 0,1+10 \cdot 0,1+10 \cdot 0,1+10 \cdot 0,1 \\
=10\end{array}$ & $\begin{array}{l}I_{\mathrm{c}}=7 \cdot 0,1+7 \cdot 0,1+7 \cdot 0,1+ \\
7 \cdot 0,2+6 \cdot 0,1+6 \cdot 0,1+7 \cdot 0,2+0,1 \cdot 0,1 \\
=6,11\end{array}$ & $\begin{array}{l}I_{\mathrm{c}}=8 \cdot 0,1+8 \cdot 0,1+9 \cdot 0,2+ \\
8 \cdot 0,2+7 \cdot 0,1+8 \cdot 0,1+7 \cdot 0,1+0,2 \cdot 0,1= \\
7,22\end{array}$ \\
\hline$I_{t}$ & $I_{\mathrm{t}}=\sqrt[0,4]{1^{0,1} \cdot 1^{0,1} \cdot 2^{0,2}}=1,41$ & $I_{\mathrm{t}}=\sqrt[0.3]{0,7^{0,1} \cdot 0,7^{0,1} \cdot 0,7^{0,1}}=0,66$ & $I_{\mathrm{t}}=\sqrt[0,4]{0,8^{0,1} \cdot 0,8^{0,1} \cdot 1,8^{0,2}}=1,2$ \\
\hline li & $I_{\mathrm{i}}=\sqrt[0,6]{2^{0,2} \cdot 1^{0,1} \cdot 1^{0,1} \cdot 1^{0,1} \cdot 1^{0,1}}=1,26$ & $I_{\mathrm{i}}=\sqrt[0,7]{1,4^{0,2} \cdot 0,6^{0,1} \cdot 0,6^{0,1} \cdot 1,4^{0,2} \cdot 0,01^{0,1}}=0,54$ & 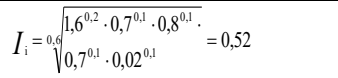 \\
\hline$I_{r t}$ & $I_{\mathrm{rt}}=\sqrt{1,41^{0,4} \cdot 1,26^{0,6}}=1,15$ & $I_{\mathrm{rt}}=\sqrt{0,66^{0,3} \cdot 0,54^{0,7}}=0,76$ & $I_{\mathrm{r}}=\sqrt{1,2^{0,4} \cdot 0,52^{0,6}}=0,86$ \\
\hline
\end{tabular}

Sources: calculated by the authors.

The given formulas characterize the use of the method of calculation of the average geometric value and include consideration of the degree of weight of each indicator of the block of technological readiness indices and the block of innovations. The authors argue that the consideration of the importance of the indices of the technological readiness block and the innovation block in assessing the country's competitiveness and its ability to conduct the radical transformation of the business processes leads to an increase in the reliability of the evaluation, which in turn leads to the adoption of sound management decisions regarding the establishment of the level of readiness to carry out the radical transformations of the business processes and their further implementation at the industrial enterprises.

The calculations of the competitiveness level of the business entities in Switzerland, South Africa, and Ukraine, based on the use of methods of weighted average and geometric average, proved that the maximum value of $I_{c}\left(10\right.$ units), $I_{r t}(1.15$ units) is of the leader country of Switzerland, which characterizes the high level of competitiveness and readiness of the enterprises of this country to carry out the radical transformations of the business processes. The second and third place, among the analyzed countries, with the figures $I_{c}\left(7.22\right.$ units), $I_{r t}\left(0.86\right.$ units) of South Africa, and with the indices $I_{c}\left(6.11\right.$ units), $I_{r t}(0,76$ units) of Ukraine, characterize the sufficient level of competitiveness and readiness of enterprises of this country to carry out the radical transformations of the business processes.

The recommendations for Switzerland, Ukraine and South Africa to improve competitiveness and readiness to carry out the radical transformations in the activities of the industrial enterprises are as follows: to maintain a leading position on the competitiveness level in the market through the introduction of radical innovations at the enterprises, the formation of a new strategic vision of the activities of innovative enterprises under the conditions of the V and VI Technological Structure (Switzerland); to develop FDI and technology transfer in the production activities, through the cooperation with investment companies, business angels, government and strengthen the introduction of new technology at the enterprises (South Africa); increase the cost of industrial enterprises for R\&D through the state support and the formation of spin-off companies; to strengthen the extension between universities and industrial enterprises in the field of R\&D through the creation of an innovations fund at the regional level and to increase the level of products patenting at the expense of the legislation (Ukraine).

The basic prerequisites that characterize the necessity of the radical transformations of the business processes (various types of re-engineering) at the industrial enterprises are defined, which include:

- a low level of implementation of the latest technological processes in the industry of many developing countries;

- an absence of free current capital for the effective business processes of the manufacturing 
companies in developing countries;

- an inconsistency of the industrial products manufacturing with the international ISO standards in the countries that manufacture products only for the domestic market or in the countries of the transition economies;

- a low level of activity of the state institutions in financing the development programs of the industrial complex and guaranteeing the protection of national interests of commodity producers at the state level.

Based on the assessment of the competitiveness and readiness of the industrial enterprises for the radical changes at the global level, we shall examine the methodological principles of the organizational and economic provision (mechanism) of the radical transformations of the business processes, which contain the indicator elements of the economic instruments for the radical changes at the industrial enterprises. We shall form the blocks of organizational and economic support of the radical transformations of the business processes.

Theoretical support block. This block contains the basic economic theories, which principles influence the implementation of the radical transformations of the business processes. According to the authors, the economic theories are the theory of competition, the theory of economic systems, and the theory of management. The principles of the formation of this mechanism are equilibrium, which contains the balance of income and expenditure in the implementation of the radical transformations of the business processes; growth, which characterizes an increase in the level of indices such as quality, service, quantity of products; synergy, which includes the formation of an additional effect from the interaction of the components of mechanism of the radical transformations of the business processes; realism, which reflects the consideration of current factors that influence the adaptation of the enterprise in the process of radical changes to the conditions of the market environment.

Organizational support block. This block includes the entities of carrying out the radical transformations of the business processes, which include management, leading managers and specialists of industrial enterprises, officials of the state authorities, members of investment and consulting companies, personnel of technological parks and technopolises, representatives of the world donors. In addition, this unit includes a system of motivational staffing, which conducts the business processes re-engineering of the industrial enterprise.

Methodological support block. This block contains a methodical toolkit for assessing the necessity and effectiveness of implementing the radical transformations of the business processes, namely: the method of economic and statistical analysis, to study the current economic situation of an industrial enterprise; forecast method, to consider the future model of an economic activity; the method of expert evaluation, to assess the qualitative indicators of the necessity and effectiveness of the radical transformations; the method of regression analysis, establish the correlation relations between the economic indicators during the radical redesign of the business processes; a method of system analysis, to implement a systematic approach in constructing thee elements of the mechanism of radical transformations of the business processes; the method of comparative analysis, in the economic analysis of implementation of the radical transformations in the period or in comparison with other enterprises that carry out the reengineering of the business processes; the method of strategic analysis, to identify the strengths, weaknesses, opportunities and threats of radical transformations, as well as in establishing the place of the enterprise, which conducts a radical redesign of the business processes in the leader-outsider area; the method of assessing the competitiveness in determining the domestic companies' compliance with the market conditions and its ability to compete in the global business environment. The latter method was used by the authors when calculating the indices of readiness of industrial enterprises for the radical transformations of the business processes: the index of technological readiness, the index of innovations, the integral index of enterprise readiness for the radical transformations.

Information support block. This block contains index elements of organizational and economic support 
of the radical transformations of the business processes, namely the subsystem of the input information, which includes a system of indicators: prices of competitors; cost of the production resource supply; overhead costs of production; capital costs for the re-design of the business processes; the period of carrying out and payback period of re-engineering; indices of the technological readiness unit; the block of innovations; the index of technological readiness, the index of innovations and the integral index of enterprise readiness for the radical transformations while assessing the competitiveness of the country's industrial enterprises and their ability to conduct the radical transformation of the business processes. In addition, this block is a subsystem of the source information, which includes such indicators as profitability and profitability of the redesigned business processes, the level of goodwill, and a market capitalization of the enterprise after the radical transformations of the business processes.

Tool block. This block includes instrumental economic tools that characterize the process of the business processes transformation. The authors include tax privileges, investments, financial resources from the state and non-state funds, the cost of material resources, the cost of labour resources, penalties for improperly executed contracts with the consulting companies, social benefits of the employees involved in the business processes redesign.

The main recommendations for the effective implementation of the mechanism of radical transformations of the enterprises' business processes are formed, which include:

- readiness for the radical transformations should be caused by the preconditions that influence the necessity of their conduct in the companies;

- financial support from the state authorities, which policy is aimed at systemic reform of the country's industrial sectors;

- creation of a satisfactory investment climate in the relevant industrial areas, which carry out the business processes re-engineering;

- formation of preferential taxes for the enterprises that carry out the radical transformations in order to minimize the economic risk of their conduct;

- implementation of an effective system of personal motivation, to take part in conducting the radical transformations of the business processes.

Conclusion and prospects of the follow-up research. The indices of the technological readiness and innovation unit of different countries are analyzed and the major problems in the activity of industrial enterprises are formed. The method of assessing the competitiveness of the countries and their ability to implement the radical innovations, namely the transformations of the business processes, which includes the index of technological readiness, the index of innovations, the integral index of enterprises' readiness for the radical transformations, has been applied. The authors refer to the radical transformations the types of innovation activities (new organizational structures, management methods, organizational and economic support for the radical changes, and economic instruments that are focused at assessing the business processes of the $\mathrm{V}$ and $\mathrm{VI}$ technological modes in the activity of industrial enterprises). The basic preconditions for implementing the radical transformations of the business processes at the industrial enterprises are determined. The system-forming elements of organizational and economic support of the radical redesign of the business processes are established. The main recommendations for the effective implementation of this mechanism are noted. With regard to the prospects for the follow-up research and proposals, the scientific research should be focused on the development of a system of economic indicators for the effectiveness of the radical transformations of the business processes and the applied analysis of the use of economic instruments for the radical transformations of the business processes at industrial enterprises. It is also necessary to draw attention to the study of factors that influence the effective conduct of radical transformations of business processes in different countries of the world, taking into account the application of advanced technologies by the leaders of the countries. Particular attention deserves the study of social aspects of radical changes in the work of business entities, exploring the 
motivational provision of radical redesign of business processes in the work of companies from different countries.

Funding: The material is prepared in the framework of a research project under the Grant of the President of Ukraine to the Doctors of Sciences for carrying out scientific research in 2018: "Reengineering of the business processes of a marketing sphere of industrial enterprises as a component of entering the domestic products to international markets" (0118U006322).

\section{References}

D'Espallier, B., Goedecke, J., Hudon, M., \& Mersland, R. (2017). From NGOs to Banks: Does Institutional Transformation Alter the Business Model of Microfinance Institutions? World Development, 89, 19-33 [in English].

Jetter, M., Satzger, G., \& Neus, A. (2009).Technological Innovation and Its Impact on Business Model, Organization and Corporate Culture - IBM's Transformation into a Globally Integrated, Service-Oriented Enterprise. Business \& Information Systems Engineering, 1, 37- 45 [in English].

Chan, F.,\& Jiang, B. (2001).The Applications of Flexible Manufacturing Technologies in Business Process Reengineering. International Journal of Flexible Manufacturing Systems, 13, 131- 144 [in English].

Goel, S., \& Chen, V. (2008). Can business process reengineering lead to security vulnerabilities: Analyzing the reengineered process. International Journal of Production Economics, 115 (1), 104-112[in English].

Bhushan, B., \& Pandey, S. (2015). Exploring the dynamics of network characteristics for Indian high technology entrepreneurial firms Journal of Global Entrepreneurship Research, 5 (12), 1-20 [in English].

Launonen, M., \& Kess, P. (2002). Team roles in business process re-engineering. International Journal of Production Economics, 3(77), 205-218 [in English].

Al-Somali, S., Gholami, R., \& Clegg, B. (2009). An investigation into the acceptance of online banking in Saudi Arabia. Technovation, 2 (29), 130 - 141 [in English].

Abu-Shanab, E. (2015). Reengineering the open government concept: An empirical support for a proposed model. Government Information Quarterly, 4(32), 453 - 463 [in English].

Melnyk, L.G., Kubatko, O. V., \& Kubatko, O. Vik. (2016). Where Ukrainian regions too different to start interregional confrontation: economic, social and ecological convergence aspects? Economic research, 1(29), 573-582 [in English].

Sotnyk, I. (2016). Energy efficiency of Ukrainian economy: problems and prospects of achievement with the help of ESCOs. Actual Problems of Economics, 1, 192-199 [in English].

Demeyer, S., Ducasse, S., Nierstrasz, O. (2003). Object-Oriented Reengineering Patterns,-Kaufmann, 282 [in English].

Lavigne, M.(1998).Economic Transformation in Vietnam: Some Critical Issues. MOST: Economic Policy in Transitional Economies, 4(8), 1-5 [in English].

Ebert, R. (1993). The Economic Transformation of Eastern Europe (Views from Within). Comparative Economic Studies, 2(35), 72-73 [in English].

Scott, H. (1993). Economic Transformation in Central Europe: A Progress Report. Comparative Economic Studies, 3(35), 6465 [in English].

Gabrisch, H. (1998).Transformation, Integration and Wage Convergence: a Comparison of East German and Central and Eastern European Economic Problems. MOST: Economic Policy in Transitional Economies, 2(8), 35-50 [in English].

Duarte, M. \& Restuccia, D. (2007) The structural transformation and aggregate productivity in Portugal. Portuguese Economic Journal, 1(6), 23-46 [in English].

Hanna, H. (2011). International Experience in e-Transformation. Journal of the Knowledge Economy,1(2), P.1-2 [in English].

Dev, N. \& Neetu, A. (2018). Technological Change and Employment: Creative Destruction/ N. Dev, A. Neetu // Technological Change and Employment: Creative Destruction,1-18[in English].

Levy, A. (1998). Grantland Rice, The Transformation of Authorship in America. Journal of Cultural Economics, 4(22), 289-292 [in English].

Alexeev, M. (2007).The Institutional Economics of Russia's Transformation. Comparative Economic Studies, 3(49), 476-479 [in English].

Ünal, E. (2018). An institutional approach and input-output analysis for explaining the transformation of the Turkish economy/ E. Ünal // Journal of Economic Structures, 3(7) [in English].

DeBresson, K. (1991)Technological innovation and long wave theory: Two pieces of the puzzle. Journal of Evolutionary Economics, 4(1), 241-272[in English]. 
Lorentz, A., Ciarli, T., Savona, M. \& Valente, M. (2016). The effect of demand-driven structural transformations on growth and technological change. Journal of Evolutionary Economics, 1(26), 219-246 [in English].

O'Connor, M. (1993).Entropic irreversibility and uncontrolled technological change in economy and environment. Journal of Evolutionary Economics, 4(3), 285-315[in English].

Reuben, E. \& Suenens, S. (2012).Revisiting strategic versus non-strategic cooperation / E. Reuben, Experimental Economics, 1(15), 24-43[in English].

Carayannis,E. \& Sipp, C. (2010).Why, When, and How are Real Options used in Strategic Technology Venturing? Journal of the Knowledge Economy, 2(1),70-85 [in English].

Olinyk, V., Kozmenko, O., Wiebe, I. \& Kozmenko, S. (2018). Optimal control over the process of innovative product diffusion: the case of Sony corporation. Economics and Sociology,3(11), 265-285 [in English].

Kharlamova, H., Stavytskyy, A.\& Zarotiadis, G. (2018). The impact of technological changes on income inequality: the EU states case study. Journal of international studies, 2(11),76-94[in English].

Gassot, Y. (2016).Digital Innovation \& Finance Transformation. DigiWorld Economic Journal, 103, 216 [in English].

Shevchenko, T.I., Danko, Y.I., \& Krasnorutskyy, O.O. (2018). Management of Waste Electrical and Electronic Products in Compliance with the Circular Economy: What are the Future Challenges for EU Member States? International Journal of Ecology \& Development ${ }^{T M}$. 3, 33, 47-55 [in English].

Schwab, K., Sala-i-Martin, X., Samans, R., \&Blanke, J. (2016). The Global Competitiveness Report 2016-2017. - Geneva: Cologny, 383 [in English].

M. Ващенко, D.Sc., WBM Polska Ltd (Польща);

Л. М. Таранюк, д.е.н., професор, Сумський національний аграрний університет (Україна);

ю. І. Данько, д.е.н., доцент, Сумський національний аграрний університет (Україна);

К. В. Таранюк, к.е.н., Сумський державний університет (Україна).

Оцінювання технологічної готовності країн світу до впровадження радикальних інновацій

у статті проведено аналіз наукових праць, які пов'язані з дослідженнями в сфері проведення радикальних інновацій суб'єктами господарювання. Проведено порівняльний аналіз технологічної готовності до впровадження інновацій у різних країнах світу. Зроблено відповідні висновки, на засадах бенчмаркингового дослідження, за блоками Технологічна готовність країн світу» та «Інновації». Проведено оцінку конкурентоспроможності Швейцарії, України, Південної Афррики та їх здатності до проведення радикальних інновацій, а саме трансформацій бізнес-процесів на базі показників індексу технологічноі готовності, індексу інновацій та інтегрального індексу готовності підприємств до проведення радикальних трансформацій. Інтегральний індекс готовності підприємств до проведення радикальних трансформацій містить індекс технологічноі готовності, індекс інновацій та розраховується як середньогеометричне значення індексу технологічної готовності, індексу інновацій з урахуванням ступеня вагомості зазначених індексів. Даний індекс дає можливість комплексно визначати рівень готовності промислових підприємств здійснювати радикальні трансформації бізнес-процесів, враховуючи рівень технологічної готовності та рівень інноваційного розвитку. Розглянуто проблемні аспекти в діяльності компаній промислового комплексу. Сформовано передумови до впровадження радикальних трансформацій бізнес-процесів суб'єктів господарювання. Розроблено методологічний інструментарій формування механізму трансформацій бізнес-процесів промислових підприємств, який полягає в основних системоутворюючих елементах даного механізму: блок теоретичного, методичного, організаційного, інформаційного, інструментального забезпечення, які в результаті впливають на суттєве підвищення економічного потенціалу в роботі суб'єктів господарювання після проведення радикальних змін. Сформовано основні рекомендації щодо ефеективної реалізації механізму радикальних трансформацій бізнес-процесів суб'єктів господарювання.

Ключові слова: радикальні трансформації, механізм, реінжиніринг бізнес-процесів, промислове підприємство.

Manuscript received: 04.11.2018

(C) The author(s) 2018. This article is published with open access at Sumy State University. 